\title{
Hjemmedød: Dette får sykepleiere til å bruke medikamentskrinet
}

Når en pasient skal dø hjemme, bør et medikamentskrin med lindrende legemidler være tilgjengelig. Ikke alle sykepleiere føler seg trygge på når de skal gi disse medikamentene.

Katrine Staats

Ph.d.-kandidat

Institutt for global helse og samfunnsmedisin, Universitetet i Bergen

Oscar Tranvåg

Postdoktor

Institutt for global helse og samfunnsmedisin, Universitetet i Bergen, Nasjonal kompetansetjeneste for kvinnehelse, Oslo Universitetssykehus og Institutt for helse- og omsorgsvitskap, Høgskulen på Vestlandet

Ellen Karine Grov

\section{Professor}

Institutt for sykepleie og helsefremmende arbeid, Fakultet for helsevitenskap, Oslomet storbyuniversitetet

Hjemmesykepleie

Palliasjon

Symptom

Legemidler

Terminalfase

Kvalitativ studie 
Når pasienter ønsker å dø hjemme er det viktig at hjemmesykepleiere har god kompetanse i bruken av symptomlindrende legemidler. Hensikten med studien er å utvikle ny kunnskap om hjemmesykepleieres erfaringer med å bruke medikamentskrin i symptomlindrende omsorg for hjemmeboende pasienter i terminalfase. Vi presenterer faktorer som skaper trygghet og fremmer bruken av medikamentskrinet, i tillegg til faktorer som hemmer bruken og skaper utrygghet og faglig uforsvarlige situasjoner.

Flere internasjonale studier viser at de fleste pasienter $i$ palliativ fase har et $\varnothing$ nske om å dø i eget hjem $(1,2)$. Pasienter og deres pårørende hevder at effektiv symptomlindring er en viktig faktor i forhold til muligheten til å kunne dø hjemme (3). I 2014 døde om lag 15 prosent av norske pasienter i sitt eget hjem - et tall som har vært stabilt over flere år (4).

Et viktig tiltak for å kvalitetssikre symptomlindring til hjemmeboende pasienter i terminalfase, er å bruke et medikamentskrin med legemidler som anbefales av den internasjonale konsensusgruppen National Institute for Health and Clinical Excellence, NICE (5). Medikamentskrinet er ment å være et enkelt og effektivt hjelpemiddel for hjemmesykepleiere i kommunehelsetjenesten (6). Forfatterne av denne artikkelen har nylig publisert en studie som beskriver hvilke erfaringer et utvalg norske hjemmesykepleiere har med bruken av medikamentskrinet (7).

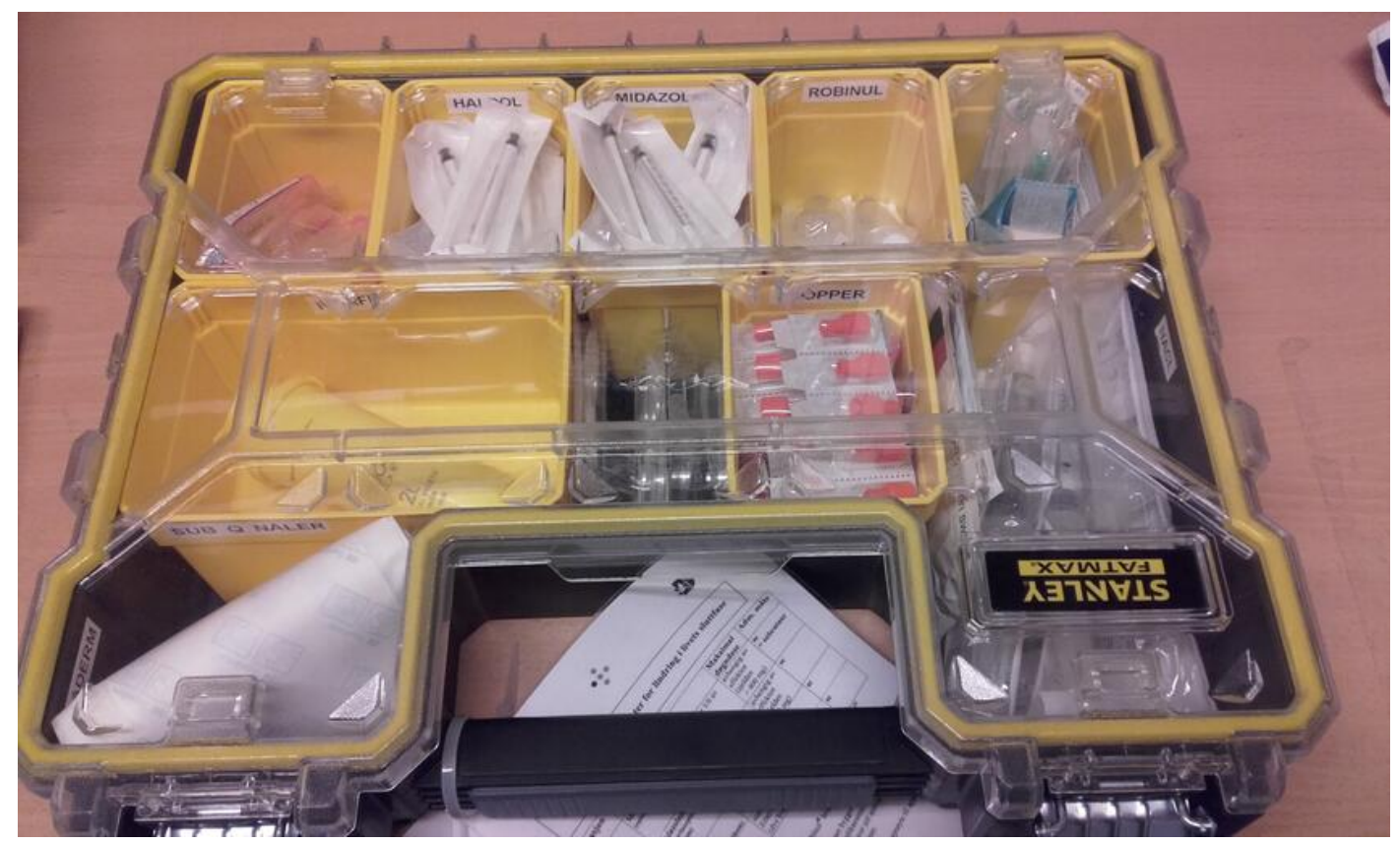

LEGEMIDLER: Medikamentskrinet inneholder legemidler som lindrer plagsomme symptomer. Foto: Privat 
Medikamentskrinet inneholder de fire legemidlene morfin, midazolam, haloperidol og glykopyrrolat (robinul), samt utstyr for å administrere legemidlene subkutant (6). En delphistudie (datasamling og drøfting i en ekspertgruppe som sammen skal avgjøre enighet om et tema) utført i ni europeiske land anbefaler at disse fire legemidlene, som i dag blir brukt i den norske hjemmetjenesten, bør være tilgjengelig $i$ alle sammenhenger hvor pasienter i terminal fase befinner $\operatorname{seg}(8)$.

\section{三 «Studier viser at skrinet er enkelt å bruke.»}

Studier viser at skrinet er enkelt å bruke og at legemidlene gir rask effekt på plagsomme symptomer (9). Når medikamentskrinet brukes etter intensjonen reduseres behovet for legebes $\varnothing \mathrm{k}$ hjemme hos pasienten. Det fører også til forlenget hjemmetid, færre innleggelser på sykehus og øker sannsynligheten for hjemmedød (10).

Det legges i dag stor vekt på å skape effektive og samfunns $\varnothing$ konomiske tjenester. Medikamentskrinet kan bidra til god lindrende behandling også på kveldstid og i helger, og kan i noen sammenhenger også administreres av pasientens pårørende $(3,11)$. Hensikten med vår studie (7) var å utvikle ny kunnskap om hjemmesykepleieres erfaringer med å bruke medikamentskrinet i symptomlindrende omsorg for hjemmeboende pasienter i terminalfase.

\section{Fakta om studien}

Metode: Studien (7) hadde et kvalitativt, beskrivende og eksplorativt design, forankret i hermeneutisk metodologi. Data ble samlet inn gjennom bruk av fokusgruppeintervju, samt påfølgende individuelle dybdeintervju, i perioden desember 2016 - mars 2017.

Utvalg: Kontaktpersoner i kommunen, henholdsvis kreftkoordinatorer og ressurssykepleiere, sto for rekruttering av studiens deltakere. Til sammen deltok 18 hjemmesykepleiere med erfaring i bruk av medikamentskrinet. De var i alderen 30-62 år. De hadde gjennomsnittlig 13 års erfaring som sykepleiere (variasjon 139 år), og sju av dem hadde relevant videreutdanning innen palliasjon og kreftomsorg. Utvalget representerte fire fylker og fem forskjellige kommuner med innbyggerst $\varnothing$ rrelse fra 5000 til 265000. 
Datainnsamling og analyse: Fokusgruppe- og dybdeintervjuer ble gjennomført på deltakernes arbeidssted. Intervjuguider ble anvendt, og førsteforfatter gjennomførte intervjuene sammen med en medforsker. En hermeneutisk analyse ble gjennomført av hver enkelt intervjutekst, og av tekstmaterialet som helhet.

Etiske overveielser: Studien er godkjent av Norsk samfunnsvitenskapelige datatjeneste (NSD), referansenummer 50589. Deltakerne i studien fikk både skriftlig og muntlig informasjon om studien, og ga sitt skriftlige samtykke til å delta.

\section{Hva fremmer bruken?}

\section{Tydelige rammer og god planlegging}

Sykepleierne var opptatt av å trygge hverandre og få til best mulig samarbeid. «Det er tross alt livets slutt, og det er en viktig del av jobben min», sa en deltaker fra en av landkommunene. Planlegging var viktig og innebar å etablere rutiner som fungerte på arbeidsplassen. Det ble også fremhevet at avklaring av legens forordninger var sentralt for forsvarlige forløp. Samtlige sykepleiere mente det var gjennomgående gode rutiner tilknyttet medikamentskrinet. Skjema og permer var utviklet for å systematisere og kvalitetssikre arbeidet. I tillegg var tilstrekkelig bemanning en viktig faktor som måtte planlegges.

En sykepleier sa: «Det er jo mange ting som må til før medikamentskrinet skal tas i bruk. Det er krevende og det tar tid. Og det er viktig at vi blir tatt ut av listene, og kan fă lov til å jobbe med det. For det tar tid å få alt på plass.» (7)

Flere sykepleiere hevdet at ved å bruke medikamentskrinet, ble organiseringen av ressursene i hjemmetjenesten bedret. Hvis bemanningen var planlagt i god tid, bidro god organisering til økt opplevelse av trygghet i deres krevende arbeidssituasjon.

\section{Avklarende møter og tilgjengelige fastleger}


Samtlige sykepleiere mente at et tett samarbeid med fastlegene, preget av kontinuitet, var en sentral faktor som fremmet god og forsvarlig anvendelse av medikamentskrinet. Det var imidlertid store variasjoner i hvordan samarbeidet mellom sykepleierne og legene fungerte. For mange av sykepleierne var fastlegen en nøkkelperson for kvalitetssikring av en forsvarlig praksis. De ønsket derfor en ordning som gjorde kontakten med fastlegen lett tilgjengelig også utenom vanlig arbeidstid. En av deltakerne uttrykte det slik:

«Noen fastleger kan du ringe til på fritida - når du ser at det er endringer som skjer - ... særlig på kvelden ... når du er alene som sykepleier og du ikke har noen å konferere med, og legevakten kjenner kanskje ikke pasienten. Jeg synes det har vært en veldig styrke når fastlegen har kommet hjem til pasienten .... fulgt med på jevnlige hjemmebesøk, og kunne vurdere dosen.» (7)

Gode forordninger fra fastlegen bidro til trygghet i oppstart og opptrapping av legemidler. Avklarende møter med fastlegen ble ansett som avgjørende for å fremme bruken av medikamentskrinet:

«Det er ikke bare medikamentskrinet, det er jo den samtalen i forkant. Tverrfaglig møte kaller de det. Den avklaringen synes jeg er veldig viktig å få, og når vi får det, så er jo det en trygghet for hjemmetjenesten.» (7)

Andre ressurspersoner som blant andre primærsykepleier og kreftkoordinator ble også beskrevet som viktige samarbeidspartnere. Sykepleierne fra landkommunene fremhevet spesielt tryggheten de opplevde når de hadde en ressursperson i tjenesten som påtok seg ansvaret ved oppstarten av medikamentskrinet hos den enkelte pasient.

\section{Dette hemmer bruken:}

\section{Manglende trygghet $\mathrm{i}$ vurdering av behovsmedisiner}

Funnene viste at medikamentskrinet til tider var sjeldent $\mathrm{i}$ bruk. Spesielt gjaldt dette landkommunene. Sykepleierne var i tillegg som regel alene med ansvaret for behovsvurdering og administrering av legemidler til alvorlig syke pasienter, noe som skapte utrygghet hos mange. 
En sykepleier i denne fokusgruppen presenterte dette utsagnet: «Det kan gå lang tid mellom hver gang vi bruker det skrinet. Så det blir litt sånn rustent etter hvert. Det man gjør sjeldent er man ikke så trygg på. Jeg følte at jeg liksom ble litt kastet inn i det, en gang som det var i bruk.» (7)

Det vil være store variasjoner i hvordan medikamentskrinet blir brukt, når sykepleiernes vurderinger er knyttet til hvilken erfaring de har med å bruke skrinet. En av sykepleierne hevdet at det mest sannsynlig ikke dreide seg om utrygghet $\mathrm{i}$ forhold til legemidlene, men om manglende trygghet $\mathrm{i}$ vurderingen av pasientens tilstand. Er det smerter? Eller er det engstelse og indre uro? Sykepleiere med lengre erfaring prøvde seg frem, og det ble ofte startet med morfin.

Nyutdannede sykepleiere opplevde det som utrygt å vurdere når pasienten skulle starte opp med andre legemidler enn morfin, spesielt legemiddelet midazolam.

En av de yngre sykepleierne uttrykte tydelig: «Det å begynne med Midazolam. Det er et sånt evig problem.» En mer erfaren sykepleier beskrev denne utfordringen slik:

«Vi hadde som sagt han med lungekreft og angst. Han hadde litt for lenge angst, slik jeg ser det da. Det ble litt dårlig håndtert. Han fikk for lite, og det var vel litt usikre sykepleiere på vakt. Da jeg kom på, så jeg at han var veldig stresset. Jeg synes doseringen var veldig lav. Jeg kontaktet legen og jeg ga morfin og midazolam med det samme. Da fikk han ro. Og da fikk hele familien ro. Der og da gjorde nok jeg en bedre jobb, sikkert fordi jeg er tryggere på det.» (7)

Sykepleiere i hjemmetjenesten jobber i stor grad alene og det kan føre til store variasjoner når det gjelder anvendelsen av medikamentskrinet. Flere sykepleiere pekte på sårbarheten som oppstår hvis uerfarne sykepleiere alene skulle ha ansvaret. En av sykepleierne uttrykte det slik:

«Hvis det er behovsmedisiner, så er jo pasienten avhengig av hvem som er på jobb, sykepleieren da. Hvilke vurderinger som blir gjort. Noen er kanskje liberale og gir mye, og noen er mer tilbakeholdne. Det kan bli veldig variabelt da hvor mye pasienten får av de forskjellige medisinene, og det er ikke sikkert det er så veldig gunstig.» (7)

\section{Sårbarhet om natten}


Sykepleierne syntes å ha en felles oppfatning av at det på nattevakter var særlig krevende å opprettholde forsvarlig bruk av medikamentskrinet. Symptomlindring i livets sluttfase kan være komplisert og det kan oppstå symptomer som må behandles der og da. En sykepleier med erfaring som nattevakt hevdet at mye avhenger av om hvorvidt dagvaktene har planlagt prosedyren rundt medikamentskrinet:

«Det at jeg bare kan fortsette på det som noen andre har begynt på. Det føler jeg er viktigst for at det skal kunne gå smertefritt i løpet av natten. Det er jo en prosedyre som kan velte hele lasset egentlig.» (7)

Studien viser imidlertid at sykepleiere på nattevakt også kommer i situasjoner hvor de må foreta vurderinger om oppstart og økning av dosene.

\section{$\equiv$ ¿Sykepleiernes trygghet og faglige kompetanse er avgjørende for kvaliteten på lindringen.»}

Sykepleiernes trygghet og faglige kompetanse er avgjørende for kvaliteten på lindringen. Vurderinger om oppstart og $\varnothing$ kning av dosene erfares av sykepleierne som utfordrende. En sykepleier som arbeider kun nattevakter uttrykte:

«Det er både spennende og skummelt på samme tid å ha ansvar for legemidlene på natt. Litt skummelt fordi jeg føler jeg står alene på natt. Jeg har liksom bare meg selv da på en måte.» (7)

\section{Avhengig av ildsjeler}

Norske kommuner er ulike både geografisk og i forhold til organisering av det palliative tilbudet. Kommunene står i utgangspunktet fritt til å organisere tjenestene på den måten de selv finner det hensiktsmessig, men de er forpliktet til å tilby nødvendig helsehjelp til personer som oppholder seg $\mathrm{i}$ kommunen (12).

Etter at samhandlingsreformen (13) trådte i kraft i 2012 har kortere liggetid på sykehus og tidligere utskrivelser av pasientene, $\varnothing \mathrm{kt}$ behovet for komplekse helse- og omsorgstjenester i kommunene. Tidlig utskrivelse til hjemmet fordrer tilgang til kvalifisert hjelp til enhver tid slik at både pasient og pårørende skal føle trygghet gjennom hele døgnet (14). 
Som studien (7) viser er det store variasjoner i hvor trygge sykepleierne er i sin vurdering av pasientenes tilstand, og i administreringen av medikamentskrinets legemidler. Det fremkommer også frustrasjon hos sykepleiere over at de ikke kan etterleve den kvaliteten de mener sykepleien bør ha.

Sykepleierne kan oppleve at de mister det menneskelige aspektet i omsorgen, og blir bærere av «organisasjonens grenser i egen kropp». De tar ansvar for det organisasjonen (kommunenes hjemmebaserte tjenester) har forpliktet seg til å gjøre. Paradoksalt nok bidrar sykepleiernes «illojalitet» ofte til at organisasjonen på denne måten «overlever» (15).

Funnene i vår studie (7) peker i samme retning; sykepleierne finner strategier for å håndtere krysspresset de befinner seg i. De brukte tid og krefter på å gjøre det beste ut av situasjonen. De hadde blant annet godtatt at de var alene på nattevakt, og at de ofte måtte foreta faglige vurderinger som de egentlig ikke kjente seg trygge $i$.

\section{Sykepleiere tar ansvar}

Sykepleiere i studien (7) mener at forordningene fra legen må være «rause» nok til at de kan starte opp med medikamentskrinet, og å gi pasienten legemidler etter egne vurderinger. Når legen ordinerer medisiner «ved behov» flyttes ansvaret for den medisinske vurderingen over til sykepleieren - en vurdering som egentlig tilhører legerollen. Flere sykepleiere i studien opplevde ansvaret for vurderingen som utfordrende.

Samtidig mente sykepleierne at «rammene», hvor sykepleieren kan trappe opp dosene til effekt oppstår, må være til stede for å benytte medikamentskrinet på en god, forsvarlig måte. For at denne praksisen skal kunne karakteriseres som faglig forsvarlig, er det en forutsetning at den enkelte sykepleier har tilstrekkelig kompetanse til å påta seg ansvaret for den medisinske vurderingen.

Paradoksalt nok viser internasjonale studier at medikamentskrinet i stor grad også blir administrert av pårørende for å lindre pasienter i livets siste fase $(10,11)$. De vil, som ufaglærte, bestemme hvilken medisinering døende har behov for. Studiene viser at bruken av medikamentskrinet er forskjellig organisert, noe som igjen reiser spørsmål om kvaliteten i den lindrende behandlingen. 


\section{Utrygge på nattevakt}

Studiens (7) funn viser at sykepleiere følte seg alene og utrygge på nattevakt. De var ofte alene og hadde ansvar for mange pasienter. Sykepleierne følte seg til tider presset til å foreta vurderinger som de ikke var komfortable med. Presset ble erfart som skremmende, og de opplevde ofte at de på nattevakter ikke hadde noen å konferere med.

\section{$\equiv$ «De var ofte alene og hadde ansvar for mange pasienter.»}

Tidligere forskning viser at mangel på erfaring og kompetanse i bruken av medikamentskrinet kan føre til innleggelser på sykehuset, og derigjennom også redusere muligheten for at pasienten, i tråd med eget ønske, kan dø i eget hjem (10).

\section{Konklusjon}

Det kan ikke trekkes generaliserende slutninger ut fra vår studie (7), men en hermeneutisk tilnærming har bidratt til $\varnothing$ kt kunnskap om sykepleiernes erfaringer knyttet til hvilke faktorer som fremmer versus hemmer god, forsvarlig bruk av medikamentskrinet hos hjemmeboende pasienter $\mathrm{i}$ terminalfasen.

Sykepleiere i studien ga uttrykk for at medikamentskrinet er et nyttig verktøy. Tydelige rammer rundt bruken av skrinet, rutiner på arbeidsplassen, samt tilstrekkelige ressurser skaper en trygghet som fremmer god og forsvarlig bruk av skrinet. Avklarende samarbeidsm $\varnothing$ ter med fastlegen, og fastlegens tilgjengelighet er forhold som fremmer faglig forsvarlig anvendelse av medikamentskrinet.

Sykepleierne omtaler også faktorer som kan svekke en faglig forsvarlig praksis. Manglende trygghet i vurderinger av symptomer hos pasienten hemmer god, forsvarlig bruk. Særlig utfordrende synes det å være for sykepleiere på nattevakt. Å være alene med ansvaret for pasienter med komplekse symptomer er krevende. Tilstrekkelig rekruttering av sykepleiere til hjemmetjenesten, og etablering av palliative team i kommunehelsetjenesten - som også er tilgjengelig på nattetid og i helger, vurderes som viktige tiltak. Slike tiltak vil fremme en faglig forsvarlig praksis, og bidra til å imøtekomme mange norske pasienters ønske om å kunne tilbringe sin siste levetid i hjemmet. 


\section{Referanser}

1. Kjellstadli C, Husebø BS, Sandvik H, Flo E, Hunskaar S.

Comparing unplugged and potentially planned home deaths: a population-based cross-sectional study. BMC Palliative Care. 2018;17:69.

2. Gomes, B, Calanzani N, Koffman J, Higginson IJ. Is dying in hospital better than home in incurable cancer and what factors influence this? A population-based study. BMC Med. 2015;13:235.

3. Rosenberg JP, Bullen T, Maher K. Supporting family caregivers with palliative symptom management: A qualitative analysis of the provision of an emergency medication kit in the home setting. Am J Hosp Palliat Care. 2015;32(5):484-9.

4. Folkehelseinstituttet. Dødsårsaksregisterets statistikkbank. Oslo: Folkehelseinstituttet; 2015. Tilgjengelig fra: http://statistikkbank.fhi.no/dar/ (nedlastet 27.10.2018).

5. National Institute for Health and Care Excellence. Care of dying adults in the last days of life. National Institute for Health and Care Excellence; 2015. Tilgjengelig fra: https://www.nice.org.uk/guidance/ng31 (nedlastet 27.10.2018).

6. Helse Bergen. Kompetansesenter i lindrande behandling. Palliasjon - verkt øy for helsepersonell. Medikamentskrin vaksne. Bergen: Helse Bergen, Haukeland universitetssjukehus; 2018. Tilgjengelig fra: https://helsebergen.no/kompetansesenter-i-lindrandebehandling/palliasjon-verktoy-for-helsepersonell (nedlastet 27.10.2018).

7. Staats K, Tranvåg $\mathrm{O}$, Grov EK. Home-care nurses' experience with medication kit in palliative care. Journal of hospice and palliative nursing. 2018;20(6):E1-E9.

8. Lindqvist O, Lundquist G, Dickman A, Bükki J, Lunder U, Hagelin CL, et al. Four essential drugs needed for quality care of the dying: a Delphi-study based international expert consensus opinion. J Palliat Med. 2013;16(1):38-43.

9. Bullen T, Rosenberg JP, Smith B, Maher K. The use of emergency medication kits in community palliative care. Am J of Hosp Palliat Med. 2015;32(6):581-7. 
10. Yap R, Lundquist G, Dickman A, Bükki J, Lunder U, Hagelin CL. Comfort care kit: use of nonoral and nonparenteral rescue medications at home for terminally ill patients with swallowing difficulty. J Palliat Med. 2014;17(5):575-8.

11. Lee L, Howard K, Wilkinson L, Kern C, Hall S. Developing a policy to empower informal carers to administer subcutaneous medication in community palliative care; a feasibility project. Int J Palliat Nurs. 2016;22(8):36978.

12. Lov $24.06 .2011 \mathrm{nr} .30 \mathrm{om}$ kommunale helse- og omsorgstjenester m.m. (helse- og omsorgstjenesteloven). Tilgjengelig fra: https://lovdata.no/dokument/NL/lov/2011-0624-30 (nedlastet 27.10.2018).

13. St.meld. nr. 47 (2008-2009). Samhandlingsreformen Rett behandling - på rett sted - til rett tid. Tilgjengelig fra: https://www.regjeringen.no/no/dokumenter/stmeld-nr-472008-2009-/id567201/ (nedlastet 27.10.2018).

14. Helse- og omsorgsdepartementet. Sammen mot kreft: Nasjonal kreftstrategi 2013 -2017. Tilgjengelig fra https://www.regjeringen.no/no/dokumenter/sammen-motkreft/id728818/ (nedlastet 30.10.2018).

15. Vike H, Brinchmann A, Bakken R, Kroken R, Haukelien H. Maktens samvittighet: om politikk, styring og dilemmaer i velferdsstaten. Oslo: Gyldendal Akademisk; 2002. 